\section{The application of Inca kbipuas an accountability and managerial control tool}

\author{
Paulo Schmidt \\ Universidade Federal do Rio Grande do Sul, Accounting and \\ Actuarial Sciences Department, Porto Alegre, Brazil \\ José Luiz dos Santos \\ Faculdade São Francisco de Assis, Accounting Department, \\ Porto Alegre, Brazil
}

\begin{abstract}
Purpose - This study aims to present the mechanisms of control and accountability used in the Inca society.

Design/methodology/approach - For this purpose, a bibliographical and documental analysis regarding the use of khipus in this civilization was carried out, applying a qualitative approach.

Findings - The results of the study indicate that the Inca khipu was the main instrument of tax registration and management adopted by the Inca empire. The Khipucamayocs were responsible for the production of the Khipu, asserting that the information generated and consolidated in the imperial khipu was correct, considering that these professionals paid with their lives in case of errors.

Originality/value - The main contributions to accounting are related to the understanding of the origin of the development of tax control and accountability tools created in the Inca Empire, before the Spanish invasions, that contributed significantly to the development of the first American societies.
\end{abstract}

Keywords - Accounting history; accounting control; Inca taxation; Inca accountability; khipus.
Received on

03/22/2016

Approved on

$12 / 07 / 2016$

Responsible editor:

Prof. Dr. Ivam Ricardo Peleias

Evaluation process:

Double Blind Review

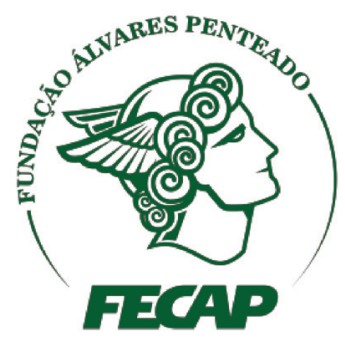

Review of Business Management

DOI: 10.7819/rbgn.v0i0.3099 


\section{Introduction}

One of the issues of current research in Accounting and Controlling has been the study of the emergence of the first signs of equity control and recording in human civilizations.

The first indications of equity control recorded in history may have been invented approximately 12,000 years ago in the Zagros Mountains, ridges situated between the countries of Iran and Iraq (Burke \& Ornstein, 2015).

In the Americas, even though recent studies by Skoglund et al. (2015) indicate that the first inhabitants originated approximately 13,000 years ago from populations of the Australasia region, which includes Australia, New Guinea and other islands in the Pacific Ocean, the first signs of equity control point to pre-Columbian civilizations responsible for the initial development of the Americas.

Among American peoples, the most prominent was the Inca Empire, which is the result from a succession of Andean cultures and which became a great pre-Columbian America empire (Oliveira, 2006).

During the Inca Empire, efficient control mechanisms of various aspects of the Incan economy were developed. According to Figueiredo (2015), the Incas created an effective tool for the control of populations and goods such as amount of gold, cut wood, produced food, etc.

Equity control in the Inca Empire was recorded in so-called khipus. Khipus represent one of the most emblematic puzzles of that Andean civilization (Ostolaza, 2006).

Urton and Brezine (2016) define khipus as textile articles made of llama or alpaca wool or cotton. It has a main cord from which many pendant strings are hung. Knots indicate numerical values according to a decimal system. The colors of the cord, in turn, indicate the item that was being counted. For each activity (agriculture, army, engineering, etc.) there was a specific symbolism of colors.
This enigmatic feature left by these coded strings, color and knot instruments carried information that could be interpreted only by experts, which caused many researchers to focus their analysis on an attempt to translate the true meaning of khipus (Ostalaza, 2006).

Studies in search of the meaning of khipus, as Bonavia (2016) demonstrated, began in 1827 with Alexander Strong, who published The Prospects of the Quipola or an Explanation of the Quipoes (London, printed by J. Phair, Westminster).

Many studies on khipus, such as those by Kenney (2014), Hyland, Ware and Clark (2014), Tokovinine (2003), Urton and Brezine (2005) and Pilgaonkar (2015), focus on anthropological analyses, examination of systemic processes of information, analyses of khipus as a logical, numeric, binary and ethno-mathematical system, the main types of khipus, structures and formats, as language and writing instruments, and even as an Incan calendar.

In addition to these lines of research, there are directed studies analyzing Incan khipus as mechanisms of accounting control, such as that by Núñez (1953), Jacobsen (1964), Primeglio (1979), Urton (2002, 2007, 2009), Forrester (1968), Negra and Negra (2009), Pasa (2001), Spalding (1973), Gentile (1992), Ramos (2015), Buckmaster (1974), Keister (1964), Tomé (2012), Urton and Brezine (2007) and Pereira (2006).

It is clear, therefore, that the interest of research on khipus, in its various aspects, covers a path of almost two centuries. However, research related to management accounting control, especially regarding tax and accountability, are less frequent and more incipient. In this context, the problem of this study is: how were tax controls and the process of accountability conducted in Incan society through khipus?

This study begins with the presentation of the research objective followed by the methodological approach, studies related to the early use of khipus, and the main procedures for tax control and for the process of accountability in the Incan society by use of khipus. 


\section{Methodological procedures}

This research is characterized as a historical study. According to Padilha and Borenstein (2005), this type of study comprises the analysis of human groups within a time frame, in which the various aspects of daily life of different social classes and groups are discussed. Therefore, within this historical research context, we proceeded to a systematic approach by collecting, organizing and critically evaluating data related to the development and the use of khipus as control and registration instruments used by the Inca people.

As for the approach to the problem, this study is classified as qualitative, considering that the research sought to address the phenomenon under study from the perspective of the people involved considering the most relevant points of view, following the methodology proposed by Padilha and Borenstein (2005).

As for the technical procedures for conducting the research, a documental and bibliographical analysis was conducted according to Luna (1996). The research began from the origin of the Inca Empire to its posterior growth to justify the importance of khipus as an essential tool for the survival of the management structure adopted by the Incan central government. As in other societies, the essentiality of fiscal and equity control is an intrinsic characteristic of development processes and consolidation of the management model implemented. Therefore, the investigative process of khipus as a tax control and an accountability instrument for the management of Inca society was operationalized through literature research and especially by documents such as photographs, museum collections and historical maps.

According to its goals, this study is classified as descriptive. Descriptive research, according to Silva (2003), aims to describe the main characteristics of a given population or phenomenon, or even establish relations between variables.

\section{The Use of khipus in Incan culture}

The purpose of this section is to present a characterization of khipus, to show how the khipu's shape, number and color were represented and how they were used by the Inca Empire.

\section{I The Inca Empire}

The Inca Empire was called Tawantinsuyu, which means "four lands" (Tawantin means the number four and suyu means "land" in the Inca language, called Quechua or Quichua).

The Inca Empire occupied an enormous area, stretching from the Amazon forest to the Pacific Ocean. In this territory, there were several types of climates and soils, allowing many peoples that were part of the Empire to produce food in excess, creating a need for the exchange of overproduction among peoples. In addition to agricultural production, some villages exercised mineral extraction activities. Such exchange of production and mineral overproduction between the four regions of the empire occurred, according to Marangon (2015), especially when the Intip Raymin (Festival of the Sun) was held in Cuzco. The peasants brought their surplus to the capital and the Emperor shared the resources among the regions so that all received everything they needed. This was possible because the Emperor had control over the production of the whole Empire.

The production control mechanism developed by the Incas was called Khipu. The Khipucamayocs (or Kipukamayoq) were responsible for the accounting used in the empire.

\subsection{The khipu}

The word Khipu, also mentioned in the literature as Khipu or Quipo, is a Quechua word that means "knot" both in singular and plural forms.

Khipu is a recording device consisting of colored cords and knots and made of cotton or wool yarns, occasionally fibers of Andean animals 
such as llama and alpaca, or, though not very common, human hair.

The strings of khipus were arranged around a main cord, called primary cord, from which many strings were hung. There may be additional strings associated with a pendant cord. Some khipus may have up to ten or more levels of subsidiary cords. According to Urton and Brezine (2016), khipus often have the primary cord stretched in the horizontal so that the pendant strings appear to form a curtain of parallel cords, or the primary cord forms a curve so that the pendant strings radiate out from their attachment points. When khipus were in use, they were transported and stored with the main cord wound up in a spiral.

Khipus were the main research topic of several studies. According to Urton and Brezine (2016), Locke was the first to argue in 1923 that the knots had a numerical significance. The Incas used a decimal counting system with numbers of variable quantities. They represented different numbers according to the type of knot and the location of the knot on the cord. At Harvard University, Urton (2016) created a database on khipus, in which information of all khipus ever identified is stored. Figure 1 shows a Khipu model recently discovered in Peru.

Mena (2016) states that Incan khipus could have more than eight million combinations due to their different colored ropes, distance between strings, positions and possible types of knots.

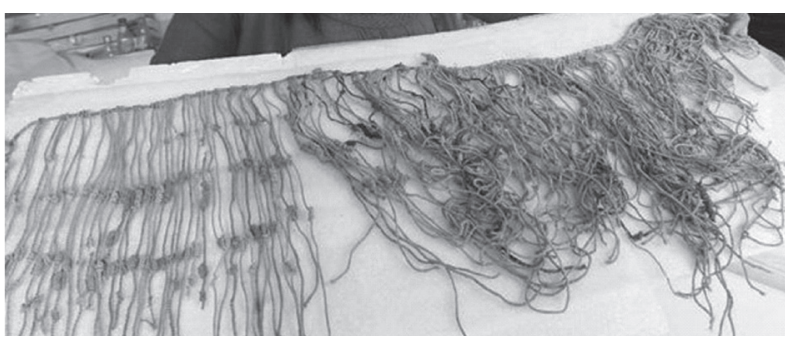

Figure 1: Khipu model discovered in Peru

Source: Retrieved from "Archaeologists find 25 Quipus at Inca site in Peru”, Andina \& H. Vinces, 2014.

\subsection{Khipus and numericalrepresentation}

Regarding the numerical representation used in khipus, according to Saez (2014), the Incas used a counting system with ten as its base, similar to Western numbering systems, i.e., from one to ten. Although Khipucamayocs used the concept of zero to denote an empty space, i.e., the absence of a knot in a certain position, the Inca system did not have a visual symbol for zero.

There are three types of knots placed in pendant cords used to encode decimal numbers in khipus. According to Pilgaonkar (2015), the long knots are used to record numeric units. Their value depends on the number of rounds that are used. There is an exception for the number one, since it is represented by a knot in the shape of an eight. Figure 2 shows knot models used by Khipucamayocs to represent numbers in khipus.

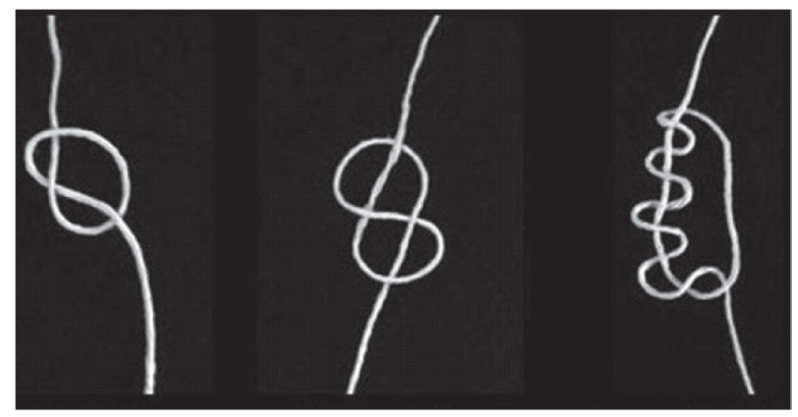

Figure 2: Knot models used in khipus

Source: Retrieved from "Mr. Barton's Ap Word History. Types of quipu knots”. G. Acosta, 2015.

Figure 3 shows a Khipu model with one primary cord, two pendant strings, one cord representing the number 327 and the other the number 2,461 .

This counting system allowed the Incas to manage their assets not only by qualitative factors, but also by using a quantitative approach. 


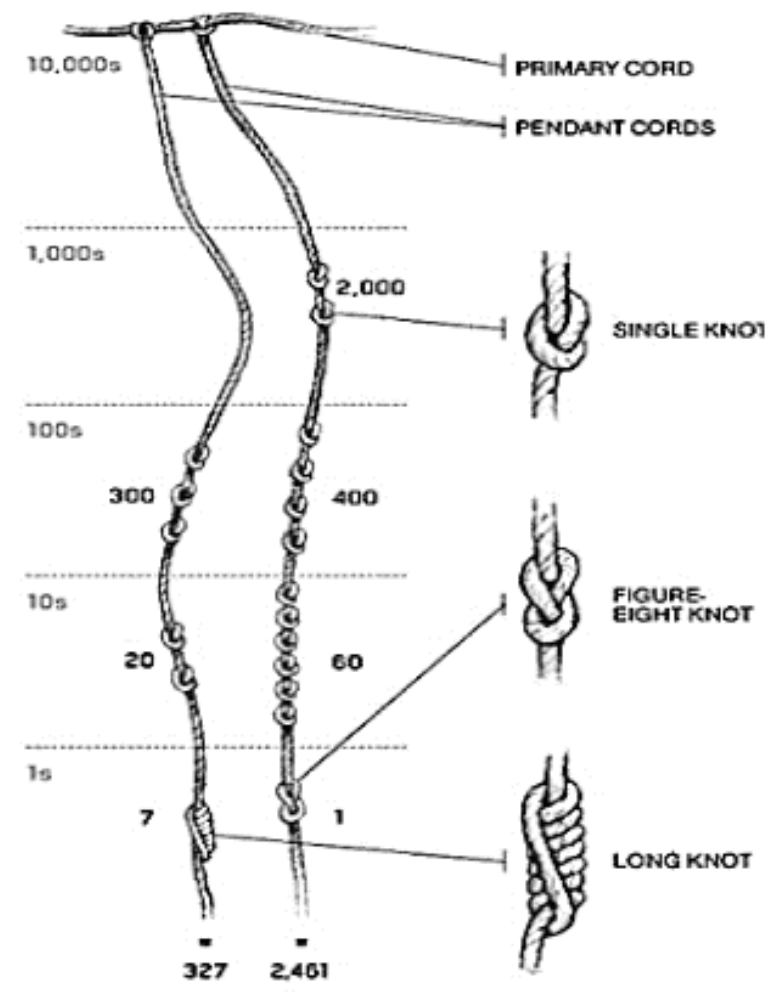

Figure 3: Khipu with a numerical representation

Source: Retrieved from "The Khipu-Based Numeration System”, S. Pilgaonkar, 2015.

\subsubsection{The Khipu and the representation by cord color}

As the knots had special features to represent the coding of decimal numbers in a Khipu, the colors of the cords also characterized the nature of the asset being recorded. As Primeglio (2006) states, it is very difficult to determine accurately the meaning of the colors, because many strings were destroyed, burned or stained, and few conserve their original pure color.

The colors were fundamental for the symbolic control system that used khipus. However, the color code could have different meanings depending on those responsible for its production (Ascher, 1981)

For Gumbrecht (1998), Aguiar (2006) and Mena (2016), the exact meaning of the colors was lost after the Spanish invasion. However, there is much speculation about the context in which they were used. The more accepted meanings for the colors of Khipu cords are brown: property assets of the Inca government and crimson (strong red): Inca assets. According to Bernand and Serge (2001), that was the color of noble Incas; purple: Curaca properties (governor of one of the Inca regions); green: assets from pillages after attacks to other populations, used to record the number of dead (they could even have been used for recording production of various crops); red: goods used in war, as well as counting of farmers, soldiers, civil servants, people and their crafts; black: weather information; yellow: information on the amount of gold in imperial wealth, the yellow represented corn accounting; white: information on silver, white for silver or vegetables in the accounting of agricultural production such as potatoes; blue: may have been used for minerals, which had only a ceremonial value for the Incas.

According to Inkarricamac (2015), khipus should be analyzed based on the colors they were created in, depending on the area where they were used to account for military, political, economic, agricultural, fishing control assets, etc.

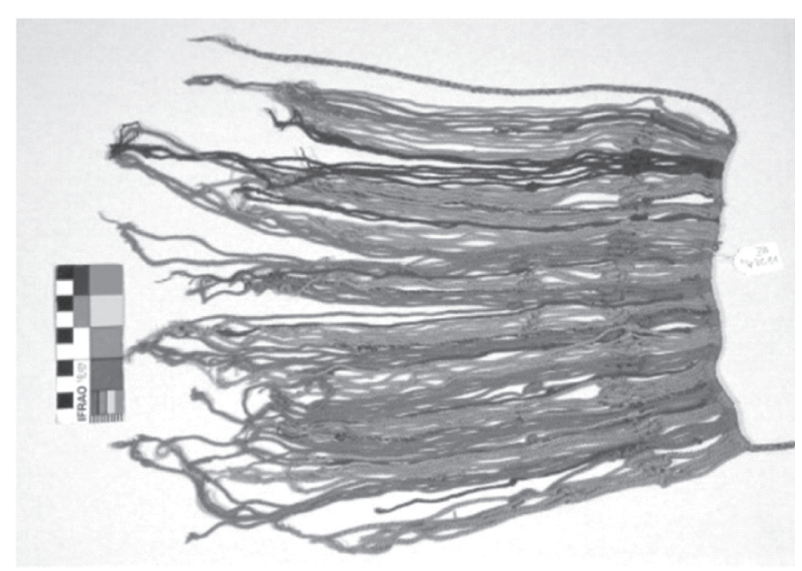

Figure 4: Khipu with cords of several colors

Source: Retrieved from "Khipu”, Staatliche Museen, 2015.

Figure 4 shows a Khipu with multiple colors, measuring $24 \mathrm{~cm}$ by $20 \mathrm{~cm}$, discovered in Ica in Peru, made between 1400 and 1550, which is part of the Staatliche Museen collection in Berlin. 
Therefore, it is clear that the adoption of the colors of the cords in khipus, for asset controlling purposes depended directly on the person responsible for their making, i.e., the Khipucamayocs. Each had its own code, although there was a tendency to use similar colors for the controlled assets and the colors of the cords.

\section{Accounting and the use of khipus}

This section shows how khipus were used in Incan society as a tax accounting control tool of the empire and how the process of accountability to the central government was made. Accounting, in this culture, was essential for tax collection from the population and the control of the economic activities of the Inca Empire (Hernández, 2014).

\section{I The use of khipus as an Incan accountability instrument}

Although the Incan people had no writing system, this did not prevent from developing a complex accounting system using khipus (Mena, 2016; Hernández, 2014).

Khipus served as the Incas's main instrument of accountability. Accountability arises from the need for reporting (disclosure) to multiple information users of an entity.

This relationship between accountability and the use of khipus can be understood from the obligation that those responsible for Incan information had to do the accounting, especially Khipucamayocs, who were required to account for and report to the central power all equity and tax handling of the empire.

According to Tun (2015), khipus were divided into two categories: numerical khipus and narrative khipus. Tun (2015) states that Jesuit priests made a distinction between numerical khipus, which were used to record ordinary things, from narrative khipus, which were used to record religious secrets and the history of the Incas. The focus of this study are the numerical khipus.

The Incan civilization developed a system of numerical records. In it were the imperial accounts containing the number of deaths and births, the quantity of what was produced, agricultural production, accumulated wealth, etc. (Aguiar, 2015).

Khipus were used to control various Incan assets such as livestock (horses, horse feed and livestock farmers debts), census (people working with shepherding, the sum of people who formed a village [ayllus], the number of men sent to war, taxable persons, residents of each village, residents of each province, mature men over fifty, people above forty, breastfeeding children, women's age, those married, the widowed, people who died in wars, people who were born and died, missing persons and all relevant information related to the population of the empire); food (eggs, chicken, quails, herbs, coca, corn, potato flour, oil, vegetables and potatoes); economy (taxes, silver, expenses, contributions from the provinces, wealth of gold, value of sold things, accounts of business held in the empire, and what should be paid in these transactions); geography (land, houses, fertile lands, land resources, mountains, productive fields, mines, metal, salt, ground measurements, cities, provinces and fortresses); other goods (clothing, wood, milk producers accounts and information about what was sold to people outside the empire) (Tun, 2015).

The Inca Empire was divided into four regions called Suyus, governed by an $A p u$ (or Apo). These regions were divided into provinces governed by Tukriquqs (or tukrikuks), with about 40,000 people each. Below the Tukriquqs were the Kurakas, who coordinated groups of 10,000 people divided into groups of 1,000 individuals under the command of a less powerful Kuraka, and so on up to a small group of 50 people also headed by another Kuraka.

The economic base of the Inca Empire, according to Salcedo and Oliveira (2012), was agriculture and livestock. To carry out these activities, it was necessary to use lands, which had a single owner: the Inca. However, in practice, the lands were distributed into three social sectors: the lands of the Inca, the lands of the Sun (lands of the religious), and the lands of the community in 
which the people worked for their own and the State's survival (Orellana, 2012).

All accounting control process of the production and taxes recorded in khipus followed the logic of stratification of the Incan society based on hierarchical structure in which each Kuraka should be accountable to another superior, this to Tukriquqs, the other to the Apus, up to the Inca emperor, who received the consolidated equity of the Empire's accounts.

Negra and Negra (2009) state that the accounting control of imperial assets was made by comparing new and old khipus. Moreover, they argue that the khipus had qualitative characteristics according to the use of each horizontal and vertical cord, defending the idea that horizontal cords represented financial groups, whose purpose was to record phenomena of a same nature, such as the collection of taxes, inventories, etc., and the different colored vertical cords represented the accounting itself.

However, according to Ascher (1981), Gumbrecht (1998), Aguiar (2015), Mena (2016) and Urton (2002), the colors could have different meanings depending on the people responsible for the Khipu production, indicating that the real meaning of the colors was lost after the Spanish invasion. Similarly, considering that the making of khipus depended directly on the Khipucamayocs, stating that the main cord (horizontal) aimed to record phenomena of a same nature seems difficult to prove; although it could be true in some cases, generalizing this claim lacks investigatory evidence.

The vertical cords truly represented specific equity items with specific quantities, which may certainly characterize different financial accounts.

Another factor identified by Negra and Negra (2009) was the association of khipus to accounting records by double-entry. The authors argue that the khipus were also double-entry instruments with a single counterpart: the State.

The book-keeping system by doubleentry in the school of accounts, the first school of accounting thinking, as presented by Schmidt and Santos (2008), observed the following logic: the recipient owes (debt record) and who delivers has values to be received (credit record). Similar to the first school of accounting thinking, Negra and Negra (2009) argue that khipus were made using double records, therefore double-entry, with the State being the sole account creditor. However, they would have difficulty to prove this statement, considering the little understanding that many scholars such as Primeglio (2006) and Urton (2002) have on the proper functioning of khipus. Other authors go further and cast doubts on the possibility that the khipus used a doubleentry system (Bonilla, 2013; Buckmaster, 1974), claiming that, to provide a full explanation of the double-entry mechanism in khipus, it would be necessary to analyze a higher number of khipus in addition to those already known.

Although there is no certainty about the many features of khipus, the process of accountability (disclosure) to the Incan central power followed a hierarchical logic with three interrelated levels.

The local khipus from regions controlled by a Kuraka portrayed the assets of the Inca and the taxes owed by the population. These were consolidated in khipus from the administrative centers of the Empire, commanded by a Tukriquq, which, in turn, would synthesize all administrative centers in a general Khipu to be presented to the Inca (Medelius \& Luna, 2004).

Thus, it is evident that the khipus, even without a precise proof of their accounting meaning, served as the main instrument for the accountability of the Inca Empire, both due to their equity and tax records and as disclosure tool at various levels of Incan society.

\subsection{Khipucamayocs (or Kipukamayoqs): responsible for records in khipus}

The Khipucamayocs were responsible for the management of khipus. Their role was population counting and recording of all the empire's asset movements. Considering the importance of their activity, according to Ferreira 
(1991) and Mena (2016), the Khipucamayoc should belong to the Inca ethnicity, whereas other workers could belong to other ethnic groups provided they were acculturated by the Inca. According to Mena (2016), the Khipucamayocs were treated as the empire's accountants.

As stated by Signorino (2015), each Khipu is unique. Thus, when comparing it to a Western writing system, each Khipu would be a unique manuscript. This statement is due to the fact that there was not only a single Khipu model. Its structure depended directly on the Khipucamayoc responsible for its production. For Tun (2015), the khipus were specific to each Khipucamayoc. A Khipucamayoc of a region could not understand the Khipu from another location of the empire, although, in general, the Incan khipus had a standard form comprised of a thicker upper cord, pendant strings of several colors and knots with standard formats. They could be used for varied purposes.

For Primeglio (2006), only Khipucamayocs were capable to read the meaning of the combination of colors and knots of a Khipu. For him, the interpretation would be like reading signs of a traditional writing system based on characters.

The Khipucamayocs were highly trusted professionals by Inca leaders and, for Gambirazio (2015), the Khipucamayocs never made mistakes because a mistake cost them their lives. He adds that the number of Khipucamayocs spread throughout the empire was proportional to the size of each locality. Small places had four and other places had 20 or even 30 Khipucamayocs (Gambirazio, 2015; Urton \& Brezine, 2007).

The Inca emperor preferred to keep several professionals working together even in places where one Khipucamayoc was enough, he kept up to four, considering that, if several people took care of the same accounting, there would be less risk of errors being made (Gambirazio, 2015).

The local Khipucamayocs from Ayllus villages could keep reusable khipus with local codes. They could modify the information according to registration requirements and disclosure of the different assets and activities of the population. The Khipucamayocs that generated consolidated information to the central power had their khipus filed in special places and used imperial codes to make their khipus (Moscovich, 2008).

\subsection{Incan tax system}

The Inca Empire adopted a distinctive form of taxation for its citizens, considering that the payment of taxes due was never carried out in cash, but in temporary collective work, temporary personal service and delivery of goods to the government, reaching the entire population from 25 to 50 years old.

The non-adoption of a currency was a practice in the economy of the Inca Empire. According to Ferreira (1991), as they did not use currency, trade relations were based on simple exchanges, and taxes levied by the central government allowed the movement of goods throughout the empire. Everything was strictly controlled by the central government. All commercial traffic conducted only by exchange obeyed rules of dates and locations previously determined both by custom and by legal norms.

The first kind of tax levied by the State, highlighted by Fernandes (2010), was farm work, according to which the tax debtor exercised his craft collectively in imperial lands, causing the State to accumulate a considerable number of agricultural products to support its bureaucracy and its military personnel, besides serving as a buffer stock in times of agricultural crisis.

The second possible form of tax payment was provision of personal service, known as mita, in which several men left their community and made themselves available to the State for various activities such as construction and maintenance of public infrastructure, construction of dams, aqueducts and warehouses, caring for State herds, weaving and agriculture activities, picking of products in the field, forests, rivers and lakes, etc. (Dell, 2010). These activities were important to the State since they allowed for the adoption of 
a redistribution system of excess goods to needy areas.

According to Fernandes (2010), this redistribution only was possible because the central government had full control over the populations of the empire and of the towns conquered during the expansion of the Inca territory, delegating economic and political power to the heads of the villages who had direct responsibility over the mechanisms for the provision of personal service to the population. Khipus were used not only for the registration of tax debts, but also to record the hours worked by debtors to the State.

The other form adopted for the collection of taxes was the delivery of goods to the State, such as clothes, shoes and other materials. The goods collected as taxes were stocked in imperial deposits and were distributed to needy populations as needed. All this storage of goods and labor as taxes was strictly recorded by Khipucamayocs in local khipus, consolidated in higher level khipus and subsequently taken to the accountability of the Imperial Council.

As stated Fernandes (2010), if a citizen married before he was 25 years old, he would pay taxes, for, to the Inca culture, marriage represented becoming a community member, which forced the person to contribute to State taxes.

The control of tax payment followed a highly hierarchical process adopted by the empire so that no debtor failed to pay his debts. For Urton and Brezine (2005), with the use of data recorded in khipus, the Khipucamayocs controlled the accounts of taxes and the tasks assigned to the numerous employees from different locations. The control was performed at the lowest level of the Inca hierarchy. Following the population stratification logic, the workers were separated into groups of five accounting units with 10 members each, totaling 50 contributors, headed by a Kuraka. One member of each group of 10 contributors held the role of leader, called Chunka Kamayoq. And, successively, according to Costa (2014), in which five of these groups formed a unit of 50 taxpayers under the authority of a
Pichqa Chunka Kuraka, two combined groups with 50 people formed a unit of 100 contributors headed by a Pachaq Kurakaand and so on, until reaching each of the four regions governed by an $A p u$. It was up to the managers of each region the obligation to keep copies of the consolidated local khipus with the accounts of taxpayers' taxes owed to the Inca and the activities of the empire's official collectors.

As advocates Tun (2015), the control process of State financial accounts through khipus needed a certain level of transparency and trust between local leaders and the central authorities so that all tax debt collected were recorded and passed on to the central coffers.

The tax collection process through records in khipus followed a logic implemented throughout the Inca territory: a socialist logic, i.e., the State's concentrated ownership, adopting the principle of planning through the balanced distribution of goods according to the population's need so that no person would be in extreme poverty, but at the same time no one could become rich neither alter the social situation in which he was born (Fleury \& Lobato, 2009; Orellana, 2012).

The tax burden was heavy and poorly distributed. The Inca, the nobility and the clergy did not pay taxes. The payment of tax debts recorded in khipus followed the rules established by the Inca inspectors, who visited localities to collect and make payments, especially when made by delivering goods (Orellana, 2012).

Thus, as in most organized societies, tax collection was part of the Inca State funding process. Khipus were the main registration, control and reporting tool regarding tax information.

\subsection{The end of the use of khipus}

The fall of the empire after the death of the Inca emperor, when the Spaniard Francisco Pizarro and his men invaded and dominated the emperor and his followers, was the beginning of the collapse of khipus.

In the opinion of Tun (2015), though scholars agree that there is no objective evidence 
regarding the destruction of the Inca culture by the Spanish, experts debate whether the prohibition of the use of khipus eliminated completely its use or if they only fell into disuse because of the dissemination of writing and the creation of a discourse by settlers against it.

The first laws directed to the extinction of khipus were created in the Third Council of Lima, in 1583, in which the Catholic Church argued that khipus were considered as idolatry instruments. This council determined the creation of teaching materials, including catechisms in Spanish, Quechua and Aymara, to instruct the indigenous peoples of Peru in the Christian faith (Cuba, 2015; Navarro, 2009).

Even with the Catholic Church's determination to abolish khipus, historians have identified some signs that khipus continued to be used for over a century after the Spanish invasion. In many cases, the settlers themselves charged taxes from the indigenous people based on records in khipus, which were still made in many localities of the Spanish colony. As pointed out by Navarro (2009), in many places there were still two or three Khipucamayocs in charge of controlling the accounts of settlements and to report the accounting to the Spanish magistrates twice a year, in June and December.

This meant that, even if the Catholic Church determined the end of the use of khipus, they were so deeply rooted into the Incan culture that it took many years to completely stop them from being used.

\section{Final considerations}

The concern with accounting control is not a recent phenomenon, nor unique to modern civilizations. The Inca society, in pursuit of that, developed a tool that was crucial to the management control of its empire: khipus.

Within this context, this study sought to uncover the procedures adopted by the Incan people to control their taxes and how the process of accountability in this society was made by using khipus.
Although the Incan khipus did not present a unique pattern for their manufacture, they represented the main tax recording and reporting management and accountability instruments adopted throughout the Inca territory. However, regardless of which Khipucamayoc produced the Khipu, all had a numerical representation using a counting system based on ten, like Western numbering systems, i.e., from one to ten, with an error level tending to zero. The person responsible for the instrument paid with his life for mistakes.

As in most modern societies, where accountants have a legal responsibility for their actions and for the information generated, the accountants responsible for tax control and accountability in the Inca Empire, the Khipucamayocs, were also punished concerning their responsibilities to society, but with the death penalty.

Another important aspect that refers to current reality is that the records in khipus formed the basis for the collection of taxes and accountability for many segments of the Inca society, akin to today's accounting system, in which accounting records underlie the calculation of taxes and provide the basis for the preparation of various financial statements for multiusers of such information.

Just as happens today with the current accounting system, as it is characterized as an applied social science, the Incan accounting suffered directly the influence of social changes. The Spanish invasion and the consequent spread of the colonizers and the Christian culture instituted by the Catholic Church meant the beginning of the collapse of khipus throughout the Inca territory.

Although many studies have been devoted to the study of khipus, there is still a great gap in the understanding of the full range of all the actual meanings of khipus. These uncertainties as to how khipus were in fact used will be the basis for further investigation. 


\section{References}

Acosta, G. (2015). Mr. Barton's ap word history. Retrieved from http://hblg-apwh.weebly.com/ quipu.html

Aguiar, N. S. (2006). A matemática dos Quipus na história da sociedade Inca. Colóquio do Museu Pedagógico, Bahia, BA, Brazil. 6. Retrieved from http://periodicos.uesb.br/index.php/cmp/article/ viewFile/1843/1666

Andina, \& Vinces, H. (2014, June). Archaeologists find 25 quipus at Inca site in Peru. Retrieved from http://www.peruthisweek.com/newsarchaeologists-find-25-quipus-at-inca-site-inperu-103338

Ascher, M. R. (1981). Mathematic of the Inca: Code of the Quipu. Michigan: University of Michigan Press.

Bernand, C., \& Serge, G. (2001). História do novo mundo: Da descoberta à conquista, uma experiência europeia (1492-1550). São Paulo: Edusp.

Bonavia, D. (2016). Prefácio. In C. Radicati Di Primeglio (Coord.), Estudios sobre los quipus (pp. 19-37). Lima: UNMSM, Fondo Editorial. Retrieved from http://sisbib.unmsm.edu. pe/bibvirtual/libros/2008/estud_quipu/ contenido.htm

Bonilla, C. O. R. (2013). La historia contable de Perú: Una pieza básica en el context Latinoamericano. Quipukamayoc, 21(40), 101112.

Buckmaster, D. (1974). The Incan Quipu and the Jacobsen hypothesis. Journal of Accounting Research, 12(1), 178-181.

Burke, J., \& Ornstein, R. (2015). Turning points in the development of contemporary society: A report on the axe maker's gift technology's capture and control of our minds and culture. Retrieved from http://Quipu.humanjourney.us/axemaker.html
Costa, A. L. M. C. (2014). Títulos de nobreza e hierarquia. São Paulo: Ed. Draco.

Cuba, O. H. (2015). The lenguas and the quipocamayocs: communication mediators in spaces of colonial legality (Peru, sixteenth century). Signos Históricos, 17(33), 8-35.

Dell, M. (2010). The persistent effects of Peru's mita. Econometrica, 78(6), 1863-1903.

Fernandes, R. L. (2010). O império Inca e a economia da América pré-colombiana (Completion of Course Work). Federal University of Rio Grande do Sul, Faculty of Economics, Porto Alegre, RS, Brazil.

Ferreira, J. L. (1991). Incas e astecas: Culturas précolombianas. São Paulo: Ática.

Figueiredo, D. J. (2015). Tawantinsuyu: O Império Inca. Retrieved from http://Quipu.klepsidra.net/ tawantinsuyu.html

Fleury, S., \& Lobato, L. V. C. (2009). Participação, democracia e saúde. Rio de Janeiro: Cebes.

Forrester, D. A. R. (1968). The Incan contribution to double-entry accounting. Journal of Accounting Research, 6(2), 283.

Gambirazio, I. (2015). Os Quipus e os Quipucamayocs. Retrieved from http://Quipu. culturaperuana.com.br/index.php/2012/06/26/ os-quipus-e-os-quipucamayocs/_

Gentile, M. E. (1992). Las investigaciones en torno al sistema de contabilidad incaico: Estado actual y perspectivas. Bulletin del Institut Français d'Études Andines, 21(1), 161-175.

Gumbrecht, Q. U. (1988). Modernização dos sentidos. Rio de Janeiro: Editora 34.

Hernández, A. P. V. (2014, junio). El Quipu: Método Ancestral para resguardar información contable. Anales Festival Internacional de Matemática, Puntarenas, Costa Rica, 9. 
Hyland, S., Ware, G., \& Clark, M. (2014). Knot direction in a Khipu/Alphabetic text from the central Andes. Latin American Antiquity, 25(2), 189-197.

Inkarricamac. (2015). Uso práctico de colores en el Perú. Los Khipus. Retrieved from http://Quipu. forosperu.net/temas/uso-practico-de-los-coloresen-el-peru.709841/

Jacobsen, L. E. (1964). The ancient Inca empire of Peru and double-entry accounting concept. Journal of Accounting Research, 2(2), 221-238.

Kenney, A. (2014). Encoding authority: Navigating the uses of Khipu in Colonial Peru. Traversea, 3, 4-19.

Keister, O. R. (1964). The Incan Quipu. The Accounting Review, 39(2), 414-416.

Luna, S. V. (1996). Planejamento de pesquisa: Uma introdução, elementos para uma análise metodológica. São Paulo: EDUC.

Marangon, R. M. (2015). Mitos ameríndios: Das primeiras civilizaçôes à conquista espanhola. Retrieved from http://Quipu.ecsbdefesa.com.br/ $\mathrm{fts} /$ MitosAmerindios.pdf

Medelius, M., \& Luna, J. C. P. (2004). Curacas, bienes y quipus en un documento toledano (Jauja, 1570). Histórica, 28(2), 35-82.

Mena, R. F. (2016). From the Aztecs their tax systems: Of the Incas their accounts, and of the Mayas their scripture; the outcome is the PreColumbian accounting. Accounting \& Financial History Research Journal, (11), 181-244.

Moscovich, V. (2008). El Khipu como registro textil en el imperio inca: ¿Herramienta de trabajo reutilizable o informe final? Iberoamerica Global, 1(2), 59-93.

Nakagawa, M. (2007). Accountability: A razão de ser da contabilidade. Revista Contabilidade \& Finanças, 18(44), 3-8.
Navarro, L. C. (2009). Los quipucamayoc y los pastores altoandinos en Canta, siglo XVI. Investigaciones Sociales, 13(23), 101-127.

Negra, C. A. S., \& Negra, E. M. S. (2009). Contabilidade no império do sol. Contabilidade Vista \& Revista, 13(3), 105-126.

Núñez, J. E. (1953). El Kipu peruano, sistema de contabilidade o estadística. The Atvidalerg International Review, 2, 29.

Oliveira, S. R. (2006). Por uma história do possivel: O feminino e o sagrado nos discursos dos cronistas e historiografia sobre o" Império" Inca (Doctoral thesis). History Department, University of Brasília - UnB, Brasília, DF, Brazil.

Orellana, E. A. (2012). Una Contabilidad Precolombiana: La del imperio incaico. Contabilidad y Auditoría, 22(11). Retrieved from http://ojs.econ.uba.ar/ojs/index.php/Contyaudit/ article/view/123/193

Ostolaza, L. F. V. (2006). La publicación de estudios sobre los Quipus Carlos Radicati, crónica del poder de la amistad. In C. Radicati Di Primeglio (Coord.), Estudios sobre los quipus (pp. 15-77). Lima: UNMSM, Fondo Editorial. Retrieved from http://sisbib.unmsm.edu.pe/bibvirtualdata/ libros/2008/estud_quipu/preli_02.pdf

Padilha, M. I. C. S., \& Borenstein, M. S. (2005). $\mathrm{O}$ método de pesquisa histórica na enfermagem. Texto \& Contexto Enfermagem, 14(4), 575-584.

Pasa, E. C. (2001). O uso de documentos eletrônicos na contabilidade. Revista Contabilidade \& Finanças, 12(25), 72-83.

Pereira, F. I. (2006). Em busca do berço da contabilidade no mundo sul-americano. Anais do Simpósio de Excelência em Gestão e Tecnologia, 2006, Resende, Rio de Janeiro, RJ, Brazil, 3.

Pilgaonkar, S. (2015). The Khipu-Based numeration system. Retrieved from http://arxiv. org/abs/1405.6093 
Primeglio, C. R. (1979). El sistema contable de los Incas. Lima: Librería Studium.

Primeglio, C. R. (2006). Estudios sobre los Quipus. Lima: Centro de Produtión Fondo.

Ramos Vargas, M. A. (2015). Un hallazgo singular de un grupo de Quipus Inca en Huaycán de Cieneguilla. Lima: Repositorio Institucional.

Saez, A. (2014). Khipu UR19: Inca measurements of the Moon's diameter and its distance from the Earth. Revista Latinoamericana de Etnomatemática: Perspectivas Socioculturales de la Educación Matemática, 7(1), 96-125.

Salcedo, R. F. B., \& Oliveira, L. (2012). O centro histórico de Cusco-Peru no passado. Seminário de História da Cidade e do Urbanismo, 4(2), 306-314.

Schmidt, P., \& Santos, J. L. S. (2008). História do pensamento contábil. São Paulo: Atlas.

Signorino, G. C. (2015). Il Khipu degli Incas. Retrieved from http://www3.unisi.it/cisai/khipu.htm

Silva, A. C. R. (2003). Metodologia da pesquisa aplicada à contabilidade. São Paulo: Atlas.

Skoglund, P., Mallick, S., Bortolini, M. C., Chennagiri, N., Hünemeier, T., Petzl-Erler, M. L., ... \& Reich, D. (2015). Genetic evidence for two founding populations of the Americas. Nature, 525(7567), 104-108.

Spalding, K. (1973). Kurakas and commerce: A chapter in the evolution of Andean society. The Hispanic American Historical Review, 53(4), 581-599.

Statliche Museen (2015). Khipu. Retrieved from http://Quipu.smb-digital. de/e MuseumPlus?service=direct/ $1 /$ ResultLightboxView/result.t1.collection_ lightbox. \$TspTitleImageLink.link\&sp=10\&sp= Scollection \&sp $=$ SfieldValue \&sp $=0 \& \mathrm{sp}=0 \& \mathrm{sp}=$ $3 \&$ sp=Slightbox_3x4\&sp=108\&sp=Sdetail \&sp $=0 \& \mathrm{sp}=\mathrm{F} \& \mathrm{sp}=\mathrm{T} \& \mathrm{sp}=115$

Tokovinine, A. (2003, Apr.). Inka Khipu: Problems and approaches. Retrieved from http://www. mezoamerica.ru/indians/south/tok_khipu.html

Tomé, C. L. (2012). A segurança: O discurso fundador e os sentidos pedagógicos em uma canção de ninar. Eventos Pedagógicos, 3(1), 101-117.

Tun, M. A. (2015). El quipu: Escritura andina en las redes informáticas incaicas Quipu colonials (Doctoral Thesis). University of Minnesota, Minnesota, EUA.

Urton, G. (2002). Signs in narrative: Accounting khipus. España: En Quilter y Urton.

Urton, G. (2009). Signs of the Inka khipu: Binary coding in the Andean knotted-string records. Texas: University of Texas Press.

Urton, G., \& Brezine, C. J. (2005). Khipu accounting in ancient Peru. Science, 309(5737), 1065-1067.

Urton, G., \& Brezine, C. J. (2007). Information control in the palace of Puruchuco: An accounting hierarchy in a Khipu archive from Coastal Peru. In R. L. Burger, C. Morris, \& R. M. Mendieta, Variations in the expression of Inka power: $A$ symposium at Dumbarton Oaks (pp. 357-384). Washington, DC: Dumbarton Oaks.

Urton, G., \& Brezine, C. J. (2016). Khipu Database Project. Retrieved from http://khipukamayuq.fas. harvard.edu/Researchers.html 


\section{About the authors:}

1. Paulo Schmidt, PhD in Controllership and Accounting, Universidade de São Paulo, Faculdade de Economia, Administração e Contabilidade, Brazil.E-mail: pschmidt@ufrgs.br

ORCID

(iD)0000-0002-7341-1316

2. José Luiz dos Santos, PhD in Economics, Universidade Federal do Rio Grande do Sul, Faculdade de Ciências Econômicas, Brazil. E-mail: joseluiz@unifin.com.br

ORCID

(iD) 0000-0002-1202-9252

\section{Contribution of each author}

\begin{tabular}{lcc}
\hline Contribution & Paulo Schmidt & José Luiz dos Santos \\
\hline 1. Definition of research problem & $\sqrt{ }$ & $\sqrt{ }$ \\
2. Development of hypotheses or research questions (empirical studies) & $\sqrt{ }$ & $\sqrt{ }$ \\
3. Development of theoretical propositions (theoretical Work) & $\sqrt{ }$ & $\sqrt{ }$ \\
4. Theoretical foundation/ Literature review & $\sqrt{ }$ & $\sqrt{ }$ \\
5. Definition of methodological procedures & $\sqrt{ }$ & $\sqrt{ }$ \\
6. Data collection & $\sqrt{ }$ & $\sqrt{ }$ \\
7. Statistical analysis & $\sqrt{ }$ & $\sqrt{ }$ \\
8. Analysis and interpretation of data & $\sqrt{ }$ \\
9. Critical revision of the manuscript & $\sqrt{ }$ \\
10. Manuscript Writing & & $\sqrt{ }$ \\
\hline
\end{tabular}

